\title{
Multiplexed assays of variant effects contribute to a growing genotype-phenotype atlas
}

\author{
Jochen Weile $e^{1,2,3,4}$ iD . Frederick P. Roth ${ }^{1,2,3,4}$
}

Received: 21 June 2018 / Accepted: 21 July 2018 / Published online: 2 August 2018

(c) The Author(s) 2018

\begin{abstract}
Given the constantly improving cost and speed of genome sequencing, it is reasonable to expect that personal genomes will soon be known for many millions of humans. This stands in stark contrast with our limited ability to interpret the sequence variants which we find. Although it is, perhaps, easiest to interpret variants in coding regions, knowledge of functional impact is unknown for the vast majority of missense variants. While many computational approaches can predict the impact of coding variants, they are given a little weight in the current guidelines for interpreting clinical variants. Laboratory assays produce comparatively more trustworthy results, but until recently did not scale to the space of all possible mutations. The development of deep mutational scanning and other multiplexed assays of variant effect has now brought feasibility of this endeavour within view. Here, we review progress in this field over the last decade, break down the different approaches into their components, and compare methodological differences.
\end{abstract}

Keywords Deep mutational scanning · MAVE · Variant effect · VUS · Variants of uncertain significance

\section{Introduction}

Linking genotype to phenotype is a very difficult problem. The parts of the human genome which we understand best are protein-coding genes, yet they only constitute a small fraction of the whole. Impacts of mutations in other functional elements such as splice sites, promoters, or regulatory sequences are more difficult to assay, not to mention the vast stretches of intergenic space. While one might expect a priori that any given intergenic variant is unlikely to bear functional significance, a large number of loci identified as correlated with diseases in genome-wide association studies

Jochen Weile

jochen.weile@mail.utoronto.ca

$\triangle$ Frederick P. Roth

fritz.roth@utoronto.ca

1 The Donnelly Centre, University of Toronto, Toronto, ON, Canada

2 Lunenfeld-Tanenbaum Research Institute, Mount Sinai Hospital, Toronto, ON, Canada

3 Department of Molecular Genetics, University of Toronto, Toronto, ON, Canada

4 Department of Computer Science, University of Toronto, Toronto, ON, Canada
(GWAS) are found within these regions (Maurano et al. 2012; Edwards et al. 2013). While many of these cases may stem from linkage disequilibrium to coding or splice-altering variants (Taşan et al. 2015), more functions yet unknown may lie hidden within this vast space. Even for protein-coding sequences, the problem is far from simple. Alleles with simple Mendelian behaviour are the exception rather than the rule. Most phenotypes are complex, i.e., they emerge through the interplay of many different genetic or environmental factors. Conversely, many genes are also pleiotropic, i.e., they are involved in more than one mechanism (Chesmore et al. 2018). As a result of this complexity, mutations found in different people may have different quantitative or qualitative effects-phenomena that are correspondingly termed variable expressivity and incomplete penetrance. Similarly, two different mutations within the same coding sequence will often differ by effect. Depending on how the translated protein is affected (e.g., catastrophic folding failure, alteration of a molecular interaction interface or active site, or a subtle change on an unused surface), the effects may differ in severity or in rare cases may even result in the emergence of qualitatively different behaviours.

Given the much greater difficulty of interpreting noncoding regions, clinical applications have so far largely concentrated on protein-coding genes. Sequencing panels 
for known disease-associated genes and even whole-exome sequencing (WES) are widely commercially available. A number of different standards for classifying mutations with respect to their potential health impacts have been proposed; most prominently, the American College of Medical Genetics and Genomics (ACMG) standard (Richards et al. 2015). It defines categories stretching from "pathogenic" to "benign", including the 'gray zone' category of "variant of uncertain significance" (VUS). Even though the mutational landscape for a handful of genes, such as $B R C A l$ are explored better than others due to their established relevance and potential for taking clinical action (Cheon et al. 2014), the majority of clinical variants across all genes are currently classified as VUS. In ClinVar alone, VUS make up over $50 \%$ of entries for missense variants (Fig. 1), despite ClinVar guidelines that actively discourage submission of unclassified variants. In a recent study using gene panels assessing germline cancer risk loci (Maxwell et al. 2016), over 98\% of missense variants were classified as VUS. Not only can these uncertainties burden patients with unnecessary anxiety (Cheon et al. 2014), they also call into question the value of sequencing in the clinic if the majority of findings are not actionable. With increasing use of WES and WGS as opposed to targeted gene panels, this problem is only going to get worse. According to the 1000 Genomes Project data, every person carries $100-400$ missense variants that are so rare that they have likely never been seen before in the clinic (The 1000 Genomes Project Consortium 2015). In the absence of the previous observations, they would automatically be added to the long list of VUSs.

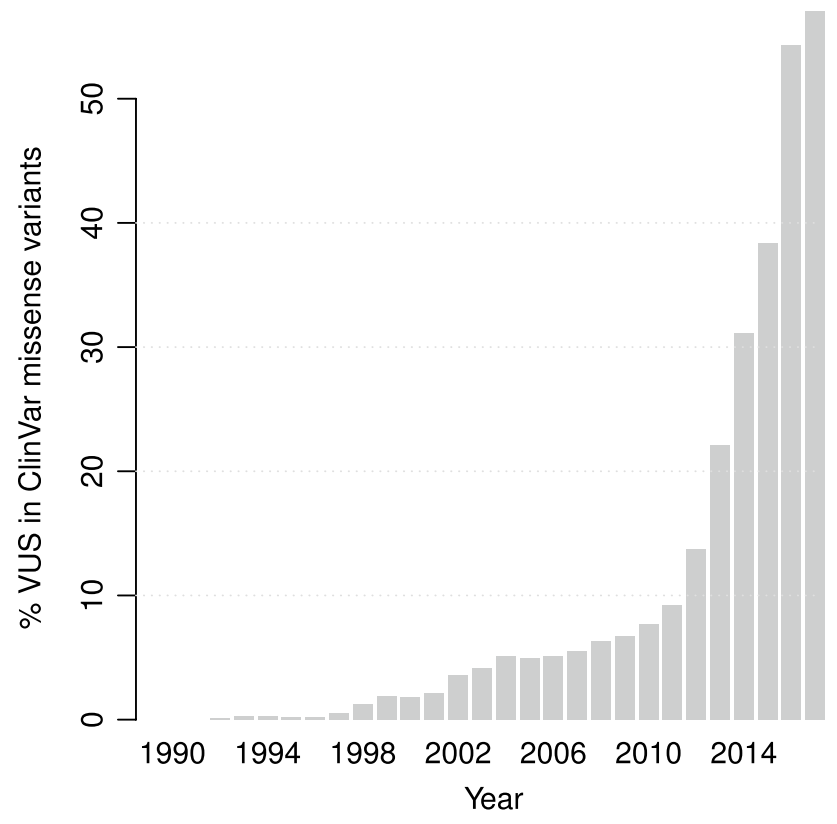

Fig. 1 Percentage of variants of uncertain significance (VUS) among missense allele Clinvar records over time from 1990 until 2017
Like its sister standards, the ACMG guidelines also recognize different methods of gathering evidence towards a variant's classification. These can be broadly summarized as (1) frequency of observation in affected or unaffected individuals; (2) laboratory assays; and (3) in silico prediction. Out of these three categories, in silico prediction used to be the only option that easily scaled to cover all possible variants and could be applied proactively. However, it is also considered one of the weakest forms of evidence. Over the last decade, however, a new type of high-throughput laboratory assay has emerged: Multiplexed Assays of Variant Effect (MAVEs) (Starita et al. 2017), which promise to massively increase the scalability of those methods that the ACMG considers in the highest tiers of evidence. In the following, we will first recapitulate some of the more popular in silico approaches and then discuss MAVEs, breaking down the methodological variety in the existing studies, describing some of the newest developments and their implications for the future.

\section{In silico approaches to variant function assessment}

A number of algorithms exist that offer predictions as to the deleteriousness of mutations, with prominent examples including PolyPhen-2 (Adzhubei et al. 2013), SIFT (Ng and Henikoff 2001), and PROVEAN (Choi et al. 2012). PolyPhen-2 employs a simple (naive Bayes) machine learning method based on evolutionary conservation and protein structural features. It uses a set of previously reported pathogenic alleles as a positive training set and differences between human genes and their mammalian homologues as a negative training set. By contrast, SIFT (Sorting Intolerant From Tolerant) only uses evolutionary conservation. The tool uses multiple sequence alignments to calculate positionspecific score matrices for each gene which are then normalized and transformed into probability values. PROVEAN (PROtein Variation Effect ANalyzer) similarly only takes into account sequence alignments. However, rather than just computing a position-specific score, PROVEAN calculates the difference in alignment quality between using the wild-type or variant sequence against clusters of homologous sequences. The average distance is then interpreted as indicative of the deleteriousness of the variant.

While the three tools succeed in making good predictions, their reliability is unfortunately still not high enough to serve as a basis of clinical decision making. We and others recently performed an independent comparison of these tools on a set of well-established disease-causing variants as well as rare polymorphisms with no known disease association (Sun et al. 2016). The study examined the tradeoff between precision (the fraction of pathogenic variant 
predictions that were correct) and sensitivity (the fraction of pathogenic variants that were predicted to be pathogenic). A high precision can be considered especially important when considering taking clinical action based on a prediction. When compared at a minimum precision level of $90 \%$, PolyPhen-2 and PROVEAN only reach a sensitivity of 19 and $21 \%$, respectively, while SIFT did not achieve $90 \%$ precision at any score threshold. Consistent with these limitations, the ACMG currently considers only cases in which multiple methodologically orthogonal prediction algorithms agree as weak evidence in a supporting role for VUS reclassification (Richards et al. 2015).

\section{Multiplex assays of variant effect (MAVE)}

An alternative to the in silico methods above are functional assays in the laboratory. Such assays are, indeed, useful tools for the classification of variants of uncertain significance. Assessment of the effects of variants observed in the clinic has led to many high-impact discoveries such as drug resistance variants in cancer genes (Solit et al. 2006; Azam et al. 2003; Shah et al. 2002; Kohsaka et al. 2017). However, experimental assays of variant function have generally been 'reactive', in the sense that measurements are carried out only after (often long after) the first clinical presentation of a variant, owing to the resource- and time-intensive nature of this testing. However, as more variants are discovered, it may be more useful to take a proactive experimental approach: Building an atlas of the functional effects of all possible variants, including those that have never before been observed in a patient. One may object that it would not be economical to screen variants that may never actually be observed in a patient. However, a simple back-of-envelope calculation given the size of the human population and the frequency of de novo mutation (Acuna-Hidalgo et al. 2016) shows that every missense variant that can possibly exist (i.e., it is not fundamentally incompatible with life) can be expected to occur on average in

$\frac{7.6 \times 10^{9} \text { humans } \times 0.6 \text { de novo exome SNVs }}{30 \mathrm{Mb} \text { exome } \times 3 \text { possible SNVs per bp }} \approx 51$ humans.

Yet, assaying all possible variants in known disease genes would require massive parallelization. Such efforts have recently gained much traction, having their foundations laid in the winter of 2010/11 with three papers by Fowler et al. (2010), Ernst et al. (2010), and Hietpas et al. (2011) that collectively pioneered a technology initially termed Deep Mutational Scanning (DMS). These seminal papers have since inspired a growing number of similar efforts by other groups. While the earliest studies of this kind focused on coding regions, multiple groups have since begun interrogating the effects of non-coding variants, e.g., on promoter activity (Kwasnieski et al. 2012; Maricque et al. 2017), autonomously replicating sequences (Liachko et al. 2013; Hoggard et al. 2016), splicing (Julien et al. 2016; Ke et al. 2018), or the behaviour of RNAs (Li et al. 2016; Puchta et al. 2016). The term "Multiplex Assays of Variant Effect" (MAVE) was coined by Starita et al. (2017) to encompass these high-throughput functional assays for a wider range of variant types.

Table 1 lists a selection of MAVE studies and their respective scales, the growth of which is shown in Fig. 2. MAVE screens can be broken down into a number of experimental and computational components: (1) mutagenesis and library creation; (2) selection of functional variants; (3) sequencing of the selected and control populations; (4) scoring and computational analysis (see Fig. 3). In the following sections, we will review the different previous implementations of these components in detail.

\section{Mutagenesis approaches}

A variety of saturation mutagenesis methods have previously been applied in MAVE studies; some more technically challenging than others. The simplest method is error-prone PCR amplification (Cadwell and Joyce 1994; Mohan et al. 2011). While this has the advantage of being an inexpensive and facile procedure, it will almost exclusively result in the generation of point mutations and as such will not generate all possible amino acid replacements. One may argue that the evaluation of VUS does not require insight into amino acid substitutions that cannot be achieved by a single-nucleotide change, as they are unlikely to occur in the clinic. However, the preference for transitions over transversions in many error-prone PCR protocols can lead to uneven representations of variants, so that codon-level mutagenesis can lead to more even representation amongst those missense variants that are achievable by single nucleotide change. In addition, multiple nucleotide changes do occur within single codons, a non-negligible $2 \%$ of the time (Kaplanis et al. 2018). Moreover, exploring all possible amino acid changes offers the potential for valuable insights into what biochemical properties may be most important for each amino acid at each position.

Another set of methods often employed are scaled-up versions of site-directed mutagenesis approaches (Hutchison et al. 1978; Seyfang and Jin 2004; Firnberg and Ostermeier 2012), with one popular example being Kunkel mutagenesis (Kunkel 1985). The Kunkel approach uses a strain of $E$. coli that has been modified to produce high levels of uridine and lacks the ability to excise these bases from DNA. A phage vector carrying the desired template sequence is transfected into the cells resulting in its replication with a high uracil incorporation rate. The 
Table 1 List of MAVE studies, their respective target spaces, and achieved levels of coverage

\begin{tabular}{|c|c|c|c|}
\hline Reference & Target & Search space & Coverage $(\%)$ \\
\hline Fowler et al. (2010) & YAP65 & WW domain & $\sim 100$ \\
\hline Ernst et al. (2010) & Synthetic PDZ domain & 10 AAs & $\sim 100$ \\
\hline Hietpas et al. (2011) & Hsp90 & 9 AAs & $\sim 100$ \\
\hline Fujino et al. (2012) & Fab antibody fragment & Fragment & 79 \\
\hline Adkar et al. (2012) & $\mathrm{Ccdb}$ & whole protein & $<74$ \\
\hline McLaughlin et al. (2012) & PSD95 & PDZ domain & $\sim 100$ \\
\hline Schlinkmann et al. (2012) & GPCR & Whole protein & $\sim 90$ \\
\hline Whitehead et al. (2012) & Synthetic protein & 51AA (whole protein) & 99 \\
\hline Traxlmayr et al. (2012) & IgG1 & $\mathrm{CH} 2 / \mathrm{CH} 3$ domains & $<50$ \\
\hline Araya et al. (2012) & YAP65 & WW domain & $\sim 100$ \\
\hline Deng et al. (2012) & TEM1 & Whole protein & $\sim 80$ \\
\hline Kwasnieski et al. (2012) & Rhodopsin promoter & 52 bp cis-regulatory element & $\sim 100$ \\
\hline Wu et al. (2013) & Neuraminidase & SNP accessible & $<50$ \\
\hline Roscoe et al. (2013) & Ubiquitin & Whole protein & $\sim 95$ \\
\hline Starita et al. (2013) & Ub.E3 E4B & Whole protein & $\sim 50$ \\
\hline Procko et al. (2013) & Synthetic protein & $60 \mathrm{AA}$ & $\sim 100$ \\
\hline Tinberg et al. (2013) & Synthetic protein & $40 \mathrm{AA}$ & 90 \\
\hline Jiang et al. (2013) & Hsp90 & Substrate binding loop & $\sim 100$ \\
\hline Kim et al. (2013) & Mat alpha & Degron region & $<50$ \\
\hline Melamed et al. (2013) & Pab1 & RRM domain & $\sim 90$ \\
\hline Forsyth et al. (2013) & Antibody for EGFR & Whole protein & $\sim 99$ \\
\hline Jacquier et al. (2013) & TEM1 & whole protein & 64 \\
\hline Hietpas et al. (2013) & Hsp90 & pos. 528-590 & $\sim 100$ \\
\hline Liachko et al. (2013) & ARS1 & $100 \mathrm{bp}$ & $\sim 100$ \\
\hline Wagenaar et al. (2014) & BRAF & 77 AAs & 99.65 \\
\hline Firnberg et al. (2014) & TEM1 $\beta$-lactamase & Whole protein & $\sim 95$ \\
\hline Olson et al. (2014) & G-protein (GB1) & IgG-binding domain & $\sim 95$ \\
\hline Melnikov et al. (2014) & APH(3’)II (kinase) & Whole protein & $\sim 100$ \\
\hline Bloom (2014) & Influenza nucleoprotein & Whole protein & $>75$ \\
\hline Thyagarajan and Bloom (2014) & Influenza hemagglutinin & Whole protein & $\sim 85$ \\
\hline Qi et al. (2014) & NS5A & IA domain & $\sim 100$ \\
\hline Roscoe and Bolon (2014) & Ubiquitin & Whole protein & $\sim 95$ \\
\hline Reich et al. (2015) & Bcl- $x_{L}$ ligands & Peptide library & N/A \\
\hline Stiffler et al. (2015) & TEM1 $\beta$-Lactamase & Whole protein & $\sim 100$ \\
\hline Doud et al. (2015) & Influenza nucleoprotein & Whole protein & $\sim 100$ \\
\hline Kitzman et al. (2015) & Gal4 & DB domain & $\sim 99$ \\
\hline Starita et al. (2015) & BRCA1 & RING domain & $\sim 80$ \\
\hline Rockah-Shmuel et al. (2015) & M.HaeIII & Whole protein & 38 \\
\hline Wu et al. (2015) & PA & Whole protein & 94 \\
\hline Mishra et al. (2016) & Hsp90 & ATPase domain & $\sim 99$ \\
\hline Doud and Bloom (2016) & Hemagglutinin & Whole protein & $<97$ \\
\hline Mavor et al. (2016) & Ubiquitin & Whole protein & $\sim 99$ \\
\hline Majithia et al. (2016) & $\operatorname{PPAR} \gamma$ & Whole protein & $\sim 99$ \\
\hline Julien et al. (2016) & FAS/CD95 & Exon 6 & 95 \\
\hline Li et al. (2016) & tRNA Arg-CCU & whole gene & $\sim 100$ \\
\hline Sarkisyan et al. (2016) & GFP & whole protein & $\sim 100$ \\
\hline Tripathi et al. (2016) & $\mathrm{CcdB}$ & whole protein & 87 \\
\hline Puchta et al. (2016) & snoRNA U3 & pos. $7-333$ & $\sim 100$ \\
\hline Brenan et al. (2016) & Mapk1/Erk2 & Whole protein & 99 \\
\hline Steinberg and Ostermeier (2016) & TEM1 & Whole protein & $39-50$ \\
\hline
\end{tabular}


Table 1 (continued)

\begin{tabular}{llll}
\hline Reference & Target & Search space & Coverage (\%) \\
\hline Hoggard et al. (2016) & miniARS317/301 & $153+135$ bp & $\sim 100$ \\
Ma et al. (2017) & BCR-ABL & 8AAs & $\sim 100$ \\
Matreyek et al. (2017) & GFP & whole protein & $\sim 60$ \\
Klesmith et al. (2017) & TEM1,LGK & whole proteins & $\sim 70$ \\
Chan et al. (2017) & IGPS & $8 \beta$-strands & $\sim 95$ \\
Bandaru et al. (2017) & H-Ras & pos. 2-166 & 100 \\
Weile et al. (2017) & UBE2I,SUMO1,TPK1,CALM1/2/3 & whole proteins & $\sim 90$ \\
Mighell et al. (2018) & PTEN & Whole protein & $\sim 95$ \\
Plesa et al. (2018) & PPAT & Whole protein & $\sim 60$ \\
Matreyek et al. (2018) & PTEN,TPMT & Whole protein & $\sim 100$ \\
Ke et al. (2018) & DHFR & exon 5 & $<50$ \\
Starita et al. (2018) & BRCA1 & 302 AAs & $\sim 85$ \\
Kotler et al. (2018) & TP53 & DNA-binding domain & \\
\hline
\end{tabular}

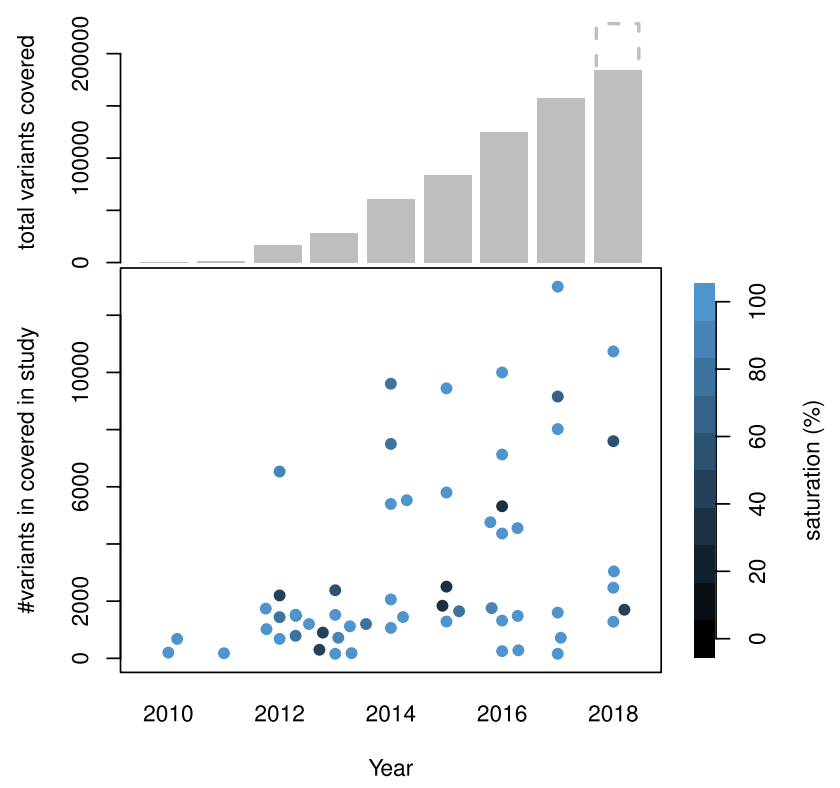

Fig. 2 Variant effects covered in MAVE studies. Top: the total number of variant effects covered in MAVE studies up to a given year. For 2018, the solid bar indicates the current state, while the dashed outline represents an extrapolation for the rest of the year. Bottom: the number of variant effects reported in individual studies, where colour indicates the study's saturation of its respective target space

thus-uracilated plasmid can then be used as a template for primer extension, with primers containing the mutations of interest, and subsequently introduced into wild-type $E$. coli which will degrade the uracilated template, thus enriching the mutant copies. A number of derivatives of Kunkel mutagenesis have since been developed to bring its output to scale supporting saturated libraries, most notably Pfunkel (Firnberg and Ostermeier 2012). To address the full spectrum of amino acids at a given position, oligonucleotides carrying degeneracy codons (Pal and Fellouse
2005) are often used. Particularly popular is the use of NNK and NNS degeneracies, which have long been used in biochemistry (Scott and Smith 1990; Barbas et al. 1992). Here, S denotes either Guanine or Cytosine, and K denotes either Guanine or Thymine in the third position of the degenerate codon. Either of these options only enables 32 out of all 64 possible codons, covering all 20 possible amino acids while avoiding two of the three possible stop codons (TGA and TAA). An alternative to degeneracy codes is the use of custom oligonucleotide arrays covering all possible (or desired) options of codon changes explicitly (Kitzman et al. 2015). While this option allows for the precise control of desired mutations, it is currently too expensive to be applicable for more than a handful of genes at a time.

Another saturation mutagenesis method often applied in Deep Mutational Scanning is EMPIRIC ("Extremely Methodical and Parallel Investigation of Randomized Individual Codons") (Hietpas et al. 2011). In this method, rather than using PCR amplification, oligonucleotide cassettes carrying the variants of interest are directly ligated at the appropriate positions. This is achieved by designing the underlying vector, such that it omits the cassette sequence. Instead, it carries a restriction site at the equivalent position, which can be cut to create sticky ends. Pairs of oligos carrying the variants of interest can be synthesized, such that they can assemble into a fitting cassette that integrates with the vector. EMPIRIC is one example of a mutagenesis method that was explicitly developed to be used in Deep Mutational Scanning. Another example is PALS ("Programmed ALlelic Series") (Kitzman et al. 2015), which aims to limit the number of amino acid changes per library clone to only one. Oligos carrying the variants of interest are annealed to uracilated templates and linearly amplified with strand-displacing polymerase. In a second step, the template 

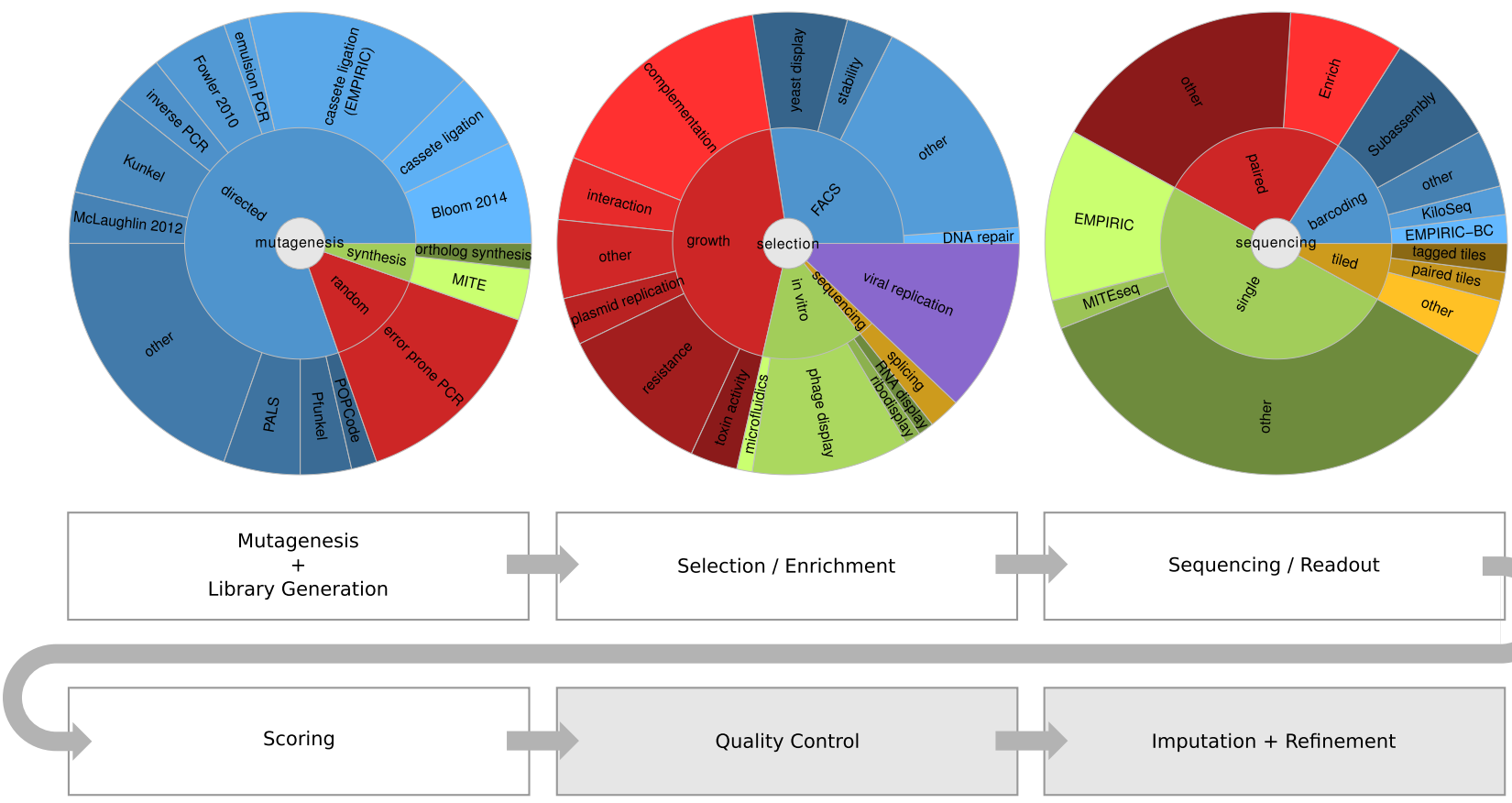

Fig. 3 Generalized workflow of a typical MAVE experiment. Steps marked in gray are downstream computational procedures not found in every study, but contribute to the quality of the data. The propor-

is degraded using uracil-DNA glycosylase and an antisense strand is generated in a second linear amplification step. The product is denatured and yet again hybridized with uracilated template allowing it to be extended towards the other end of the template. Finally, the template is degraded again and the now full-length mutagenized strands are amplified.

Yet another approach, which recently gained popularity, is dubbed "inverse PCR" (Jain and Varadarajan 2014). This method uses circular templates and pairs of oligos, one of which carries the mutagenic degenerate sequence, while the other points directly away from it. This primer setup appears like a directional inversion of that used in a regular PCR, thus lending the method its name. A first amplification step produces a set of linear products which serve as templates for the second, exponential amplification step, after which the final product is circularized. The authors compared the method to similar approaches using overlapping primers and found the inverse PCR method to display superior efficiency. This approach has become popular recently, and multiple MAVE maps have relied on it (Puchta et al. 2016; Matreyek et al. 2018).

A more recent development is "POPCode" (Weile et al. 2017), which expands upon the site-directed approach described by Seyfang and Jin (2004). Here, a set of oligos carrying all possible codon replacements are designed, such that their melting temperatures are uniform. They are hybridized to a uracilated template, in similar fashion to the PALS approach; however, they are allowed to directly compete tions of studies using different mutagenesis, selection, and sequencing methods are broken down in pie charts. Colors serve to visually differentiate different categories but do not bear meaning

with each other, enabling either single or multiple variants per molecule, depending on oligonucleotide concentrations. Non-strand-displacing polymerase is used to fill the gaps and seal the remaining nicks, followed by the degradation of the template using uracil-DNA glycosylase. A useful feature of this approach is the availability of a webtool that automates POPCode oligo design, such that each oligo arm surrounding the degeneracy has a similar melting temperature (Weile et al. 2017).

In addition to the various mutagenesis methods discussed here, it may be noted that complete variant libraries are also recently becoming commercially available via gene synthesis (Kosuri et al. 2010). A current limitation is the rate of point mutations and indels (Plesa et al. 2018), which makes it inappropriate for achieving frameshift-free coding regions with 1 aa change per clone for longer proteins. However, it is possible that, with increased interest in gene synthesis applications, these options may become more accurate and economical in the future.

Finally, with the rise of CRISPR/Cas9 and other gene editing tools, new methods are emerging that are able to introduce variants directly into endogenous gene loci, at efficiencies which are beginning to allow saturation mutagenesis. Findlay et al. (2014) first demonstrated this idea on a small scale, mutagenizing a small range of codons in BRCA1. A large-scale implementation of this idea is soon to be published (Findlay et al. 2018). Although this is currently more resource-intensive than introduction of an 
mutagenized library generated ex vivo, the advantages of studying variation in the context of the native gene locus are potentially great. For example, the function of variants that depend on the action of distal enhancers would be missed using mutagenized constructs introduced at a safe harbor site that is far from the endogenous locus.

\section{Selection approaches}

The most central component of a MAVE study is the selection process. The selection schemes used in previous studies can be sorted into four broad categories: (1) in vitro display methods (such as phage display or ribodisplay); (2) competition-based methods that couple a protein property under investigation (such as molecular interactions, toxicity, or overall functionality) to host cell fitness; (3) cell sorting based on fluorescence-labeled reporters; (4) transcriptabundance-based methods.

Phage display (Smith 1985) and ribodisplay (Mattheakis et al. 1994) couple the genetic information of each given variant to the physical protein itself and select according to the protein's ability to bind to a fixed interactor. In phage display, this is achieved by the protein being displayed on the surface of a phage that contains the corresponding gene, while ribodisplay stalls a cluster of ribosomes on the variant mRNA with the corresponding protein still attached. Variants that are unable to bind to the interactor-coated surface are washed away and thus depleted. This can be done in multiple rounds, as the associated genetic information can be replicated again after selection (via viral propagation in bacteria for phage display or via PCR in ribodisplay). Fowler et al. (2010) employed phage display in their seminal Deep Mutational Scanning study of the binding of the YAP65WW domain to its cognate peptide target. However, since display methods are only feasible for small proteins or fragments thereof, more recent studies have instead employed more scalable methods.

The most frequently applied selection mechanisms are fitness-based. In these cases, a particular property of the variant protein is coupled to its host cell's ability to thrive in competitive growth. Of these methods, functional complementation (Lee and Nurse 1987; Osborn and Miller 2007) and Yeast-2-Hybrid (Y2H) (Fields and Song 1989) are among the most frequently applied. While complementation couples fitness to a protein's overall ability to perform its biological role in a model organism, $\mathrm{Y} 2 \mathrm{H}$ couples fitness to the ability of the protein to maintain a specific protein-protein interaction.

The largest share of growth-based selection methods in MAVE studies employs functional complementation, and most use the yeast Saccharomyces cerevisiae as their model system (see Fig. 3). The assay is based on the premise that some human genes can be used to rescue the deletion of their orthologues in yeast. That is, a fitness defect resulting from the inactivation of the yeast gene is alleviated by the artificial expression of the human gene. Therefore, any relative changes in fitness upon expressing a variant of the human gene can be interpreted as the variant's effect on the protein's overall ability to function. We and others recently examined the applicability of functional complementation in yeast to the assessment of disease variants (Sun et al. 2016). This study found that functional complementation assays in yeast offered sensitive and accurate predictions despite yeast and humans being diverged by $\sim 1$ billion years. Indeed, yeast complementation outperformed in silico methods like PolyPhen-2 and PROVEAN in terms of disease variant prediction by a wide margin. At a threshold of $90 \%$ precision (as discussed in "In silico approaches to variant function assessment"), the complementation assay achieved a sensitivity of over $60 \%$, as compared to 19 and $21 \%$ for the two in silico methods, respectively. It is consistent with these findings that the ACMG considers functional assays among the strongest sources of evidence for variant classification (Richards et al. 2015).

A limitation of functional complementation in yeast is that currently only $\sim 200$ human disease-implicated genes have been found to be amenable to the assay (Sun et al. 2016). However, the existence of synthetic lethal genetic interactions for many yeast genes may allow for the design of strains with sensitized backgrounds providing new complementation assays. In addition, CRISPR screens have in recent years revealed many genes for which growth phenotypes exist directly in human cell lines (Hart et al. 2015; Blomen et al. 2015; Wang et al. 2014); opening the possibility of performing functional complementation directly in these cell lines. A number of studies have since exploited the possibility of complemention assays directly in human cells (e.g., Wagenaar et al. 2014; Qi et al. 2014; Brenan et al. 2016). However, while future variant analysis is likely to trend towards complementation in mammalian cell models as opposed to yeast, the latter assays are not obsolete. Sun et al. (2016) found that a selectable phenotype that is potentially compatible with MAVE using human cell-based complementation has been identified for less than half of all human disease genes. Thus, for many disease genes, yeastbased complementation or $\mathrm{Y} 2 \mathrm{H}$ may be the only viable option for a MAVE.

A popular condition-dependent extension to complementation is selection for drug resistance (Wu et al. 2013; Wagenaar et al. 2014), but other fitness-based selection methods have been used in MAVEs as well. For example, Adkar et al. (2012) used the toxicity of CCDB in E. coli, while Kim et al. (2013) select according to degron activity by fusing the degron to an auxotrophic marker. Finally, a number of MAVE studies have been performed on viral 
genes, by selecting for virus propagation efficiency (Bloom 2014; Thyagarajan and Bloom 2014).

Another popular growth-based assay is Yeast-2-Hybrid (Y2H). It is a binary protein interaction assay also performed within the yeast $S$. cerevisiae. Y2H is based on the reconstitution of two fragments of the transcription factor Gal4 fused to two proteins of interest. A successful interaction of the two proteins allows Gal4 to induce the expression of a reporter; usually, an auxotrophy marker. When comparing different variants of the same protein interacting with the same partner, reporter expression has even been shown to be proportional to binding affinity (Yang et al. 1995). This proportional relationship allows for quantitative interpretation of $\mathrm{Y} 2 \mathrm{H}$ results under these specific circumstances.

One objection to the use of $\mathrm{Y} 2 \mathrm{H}$ as an assay for variant function assessment is that it does not measure all aspects of a protein's functionality, but rather only its ability to physically associate with a given interaction partner. However, in addition to detecting variants that specifically affect binding, e.g., via changes to the binding interface, this approach should also detect many other variants that broadly impact protein function, e.g., those that cause protein mis-folding or instability. Indeed, in a recent examination of the $\mathrm{Y} 2 \mathrm{H}$ performance of common disease-associated variants, we found that approximately two out of three disease variants in proteins with multiple interaction partners lose some or all of their protein interactions (Sahni et al. 2015).

Another selection mechanism is the use of fluorescenceactivated cell sorting (FACS) (Julius et al. 1972). Here, surface markers for which abundance is proportional to the activity of the studied protein are targeted with fluorescently labeled antibodies, such that cells can be sorted accordingly, as has been performed by Schlinkmann et al. (2012) and Majithia et al. (2016). FACS-based selection has also been used to gain read-outs of protein stability and abundance (Matreyek et al. 2018).

In addition to assays that measure general properties of proteins, more specialized methods also exist, which assess specific molecular functions. For example, Starita et al. (2015) developed an assay that quantifies the ubiquitination activity of BRCA1's RING domain. Most recently, they also developed an assay to test the same protein's DNA-repair activity (Starita et al. 2018).

In terms of selection for the properties of non-coding regions, a number of technologies have been developed. Massively Parallel Reporter Assays (MPRAs) (Kwasnieski et al. 2012; Maricque et al. 2017) for example place libraries of mutagenized promoter sequences upstream of barcoded regions, the expression of which is measured using RNA-Seq, while the initial abundance of corresponding cells is measured by DNA sequencing of the same loci.
The ratio of RNA-Seq to DNA-Seq reads can then be used to calculate the effect of promoter variant on expression. Similarly, splicing assays such as employed by Julien et al. (2016) or Ke et al. (2018) also use RNA-Seq to measure the fraction of transcripts in which the exon of interest is spliced in.

\section{Sequencing strategies}

The experimental step immediately following selection in a MAVE experiment is sequencing. Next-generation sequencing technology can be considered the key technological advance that made Deep Mutational Scanning possible. Many studies use a fairly simple approach by performing deep shotgun sequencing of the library (Ernst et al. 2010; Hietpas et al. 2011; Fujino et al. 2012). However, a major problem with this approach is that, without knowing which reads originate from which DNA molecule, each read can only be considered by itself, making it difficult to distinguish real mutations from sequencing error. To address this problem, different solutions have emerged. In cases where the amplicon is short enough, paired-end 'duplex' sequencing can be exploited to use information from both strands for variant calling. In the simplest case, this is achieved by requiring both reads to agree on the base call in question, as in the case of Whitehead et al. (2012) and Weile et al. (2017). A less stringent, but potentially more sensitive alternative as used by Fowler et al. (2010) is to perform Bayesian inference on the quality scores associated with the base calls in each read pair. This way, a variant may still be identified if one of the two reads reported a wild-type base call with low confidence.

Where the length of the nucleotide sequence in question exceeds the read-length capabilities of short-read sequencing technologies, other strategies are required. A notable borderline case can be found in Olson et al. (2014) where only a partial overlap between read pairs was achieved and variant calls outside of the overlap region were of lower quality. Other studies have used more involved approaches. A popular paradigm is the association of molecular barcodes with each clone within the MAVE library. While this simplifies the readout of the experiment (as only the barcodes need to be sequenced and counted), it adds the requirement of identifying which barcode belongs to which genotype. In most cases, this is addressed using "subassembly" (Hiatt et al. 2010), a high-throughput amplicon sequencing approach based on attaching random tags to amplicons. The DNA is then amplified, sheared, and ligated to adapters, so that paired-end sequencing can be used to identify the random tag together with each read. This allows reads to be sorted according to which original tagged molecule they belong, which, in turn, enables separate assemblies for each input molecule to be computed. The resulting high-quality virtual 
reads are long enough to cover both ORF and barcode locus. Another subassembly approach is "KiloSeq" (Weile et al. 2017) which works using an array-based format where wellspecific tags are attached to the amplicons, followed by Tn 5 tagmentation and re-amplification of tag-bearing fragments. Another barcode-based method, called EMPIRIC-BC was described by Mavor et al. (2016), where the amplicon in question was short enough not to require subassembly. Here, a long read can cover the entire ORF, while a second, short read can identify the barcode.

An alternative approach to covering longer stretches of DNA is to subdivide them into smaller regions that can be sequenced separately from each other. For example, Doud and Bloom (2016) amplify each region with primers carrying random tags. This way, if multiple reads contain the same tag, they are highly likely to originate from PCR copies of the same original molecule and can be used to make more accurate variant calls. This approach is often dubbed "tagclustering". While this approach has the advantage of being less labour-intensive than barcoding each individual clone in the MAVE library, it can only detect variants co-occurring within the same region of the sequence. Thus the library must be designed in such a way that either only a single mutation occurs within each clone or that it is large enough that effects of many background variants are averaged out. This approach can also be used in combination with duplex sequencing, as performed in Weile et al. (2017), where it is called "DMS-TileSeq".

In a benchmark study, Zhang et al. (2016) evaluated some of these approaches. They found that duplex sequencing decreases the rate of transition and transversion base-calling errors tenfold while decreasing indel errors by 100 -fold. By contrast, tag clustering lowered transition and transversion errors 20 fold, but had a little impact on indel errors. A combination of both approaches in which tagged reads are first compared against their paired partners and then clustered is found to perform best. The authors also examined the effect of quality score filtering. While this method had moderate impact when applied to raw reads, read pairing and tag clustering benefited little from it.

\section{Computational analysis}

Most MAVE studies use custom scripts to process the sequencing readout and calculate the selection advantage for each variant. Nonetheless, a few published software packages exist. The EMPIRIC mutagenesis and screening method provides its own software package for data processing (Hietpas et al. 2011), though it is not generally applicable to other MAVE methods. The dms_tools package (Bloom 2015) offers the same services, but is tailored more towards methods using regionally focused sequencing. Finally, Enrich (Fowler et al. 2011) offers a generalized solution applicable to most DMS frameworks. A second version that adds a more sophisticated statistical analysis including the assessment of measurement confidence levels (Rubin et al. 2016).

The DMS-BarSeq and DMS-TileSeq methods used in Weile et al. (2017) also come with publicly available analysis pipelines. Most importantly, they offer imputation of missing values using machine learning. A Random Forest model (Breiman 2001) was created using physicochemical and structural features of the affected amino acids as well as position-specific biases of the existing map, yielding surprisingly accurate predictions that surpassed those of Polyphen-2 (Adzhubei et al. 2013) and PROVEAN (Choi et al. 2012). This most recent innovation has since been adapted for use with different predictive features by Mighell et al. (2018).

Going beyond the scope of predicting the effects of variants omitted within a mapped gene, Gray et al. (2018) applied machine learning to extrapolating maps for new genes. Using a gradient-boost model (Friedman 2001) trained on similar features as the imputation method from Weile et al. (2017), they implemented a new cross-validation scheme that swaps out whole proteins to be more sensitive towards the detection of overfitting. While predictions were generally more reliable than established computational predictors, accuracy was highly variable across proteins, with some performing better than others. This behaviour may be alleviated as more DMS data sets become available for training.

Beyond the potential utility of the variant effect maps in the clinic, they also lend themselves to extract new insights from computational biology. Bloom (2017) recently developed a method to detect signatures of evolutionary selection within these maps far exceeding the sensitivity of comparing orthologous sequences alone. Meanwhile, Wu et al. (2016) developed a method to calculate direct estimates for the folding energy effects of variants by examining their intragenic genetic interactions within variant effect maps.

\section{Conclusion}

Since their inception in 2010, MAVEs have produced a steadily increasing wealth of variant effect maps. Recent years have seen an increasing trend of targeting clinically relevant genes. The utility of these maps towards the eventual goal of clinical variant assessment has been demonstrated in multiple studies (Starita et al. 2015; Majithia et al. 2016; Weile et al. 2017). Since then, an arsenal of different methodologies have been developed to capture a wider spectrum of sequence types and functions. In addition, new computational methods continue to improve the quality and reliability of the data produced. 
However, a number of issues are still apparent. Many of the studies listed in Table 1 do not make their data easily available. While some provide full access to final results, some only provide raw data in the NCBI short-read archive (SRA), the majority require interested parties to contact the authors personally. There is a clear need for an open data repository that makes MAVE data available to the public and allows for downstream probabilistic integration and analysis. Similarly, the issue of reagent availability remains as a challenge. In most cases, the saturation mutagenesis libraries generated are not made available via common repositories. Furthermore, due to the large diversity of methodologies employed, libraries cannot generally be expected to be compatible across platforms.

Another complicating factor is the fact that the assays underlying different MAVE studies are quite diverse and measure different aspects of a protein's behaviour. As a consequence, they cannot be easily compared with each other. In addition, the achieved coverage of possible amino acid changes varies from map to map. Finally, many maps do not control the quality of measurements. Therefore, the confidence levels underlying different parts of these maps are often unknown. While generalized frameworks have been proposed that would increase the potential comparability and interpretability across maps (Rubin et al. 2016; Weile et al. 2017), they are not implemented by most studies. Here, a centralized repository could also be of help, as it could serve as a basis for re-analysis of data with the latest tools.

Acknowledgements The authors would like to thank Doug Fowler, Alan Rubin, Jesse Bloom, Amy Caudy, Igor Stagljar, Lincoln Stein, and Dan Bolon for their input and collaboration. The authors gratefully acknowledge funding by the One Brave Idea Initiative, the National Human Genome Research Institute of the National Institutes of Health (NIH/NHGRI) Center of Excellence in Genomic Science (CEGS) Initiative (HG004233), the Canadian Excellence Research Chairs (CERC) Program, and the Ontario Ministry of Research and Innovation (MRI).

\section{Compliance with ethical standards}

Conflict of interest On behalf of all authors, the corresponding author states that there is no conflict of interest.

Open Access This article is distributed under the terms of the Creative Commons Attribution 4.0 International License (http://creativeco mmons.org/licenses/by/4.0/), which permits unrestricted use, distribution, and reproduction in any medium, provided you give appropriate credit to the original author(s) and the source, provide a link to the Creative Commons license, and indicate if changes were made.

\section{References}

Acuna-Hidalgo R, Veltman JA, Hoischen A (2016) New insights into the generation and role of de novo mutations in health and disease. Genome Biol 17:241. https://doi.org/10.1186/s1305 9-016-1110-1

Adkar BV, Tripathi A, Sahoo A, Bajaj K, Goswami D, Chakrabarti P, Swarnkar MK, Gokhale RS, Varadarajan R (2012) Protein model discrimination using mutational sensitivity derived from deep sequencing. Structure 20(2):371-381. https://doi.org/10.1016/j. str.2011.11.021

Adzhubei I, Jordan DM, Sunyaev SR (2013) Predicting functional effect of human missense mutations using polyphen-2. In: Current protocols in human genetics. Wiley. https://doi. org/10.1002/0471142905.hg0720s76

Araya CL, Fowler DM, Chen W, Muniez I, Kelly JW, Fields S (2012) A fundamental protein property, thermodynamic stability, revealed solely from large-scale measurements of protein function. PNAS 109(42):16858-16863. https://doi.org/10.1073/pnas.1209751109

Azam M, Latek RR, Daley GQ (2003) Mechanisms of autoinhibition and STI-571/imatinib resistance revealed by mutagenesis of BCR-ABL. Cell 112(6):831-843. https://doi.org/10.1016/S0092 -8674(03)00190-9

Bandaru P, Shah NH, Bhattacharyya M, Barton JP, Kondo Y, Cofsky JC, Gee CL, Chakraborty AK, Kortemme T, Ranganathan R, Kuriyan J (2017) Deconstruction of the Ras switching cycle through saturation mutagenesis. eLife 6:e27810. https://doi. org/10.7554/eLife. 27810

Barbas CF, Bain JD, Hoekstra DM, Lerner RA (1992) Semisynthetic combinatorial antibody libraries: a chemical solution to the diversity problem. PNAS 89(10):4457-4461. https://doi. org/10.1073/pnas.89.10.4457

Blomen VA, Májek P, Jae LT, Bigenzahn JW, Nieuwenhuis J, Staring J, Sacco R, Diemen FRv, Olk N, Stukalov A, Marceau C, Janssen H, Carette JE, Bennett KL, Colinge J, Superti-Furga G, Brummelkamp TR (2015) Gene essentiality and synthetic lethality in haploid human cells. Science aac7557. https://doi.org/10.1126/ science.aac 7557

Bloom JD (2014) An experimentally determined evolutionary model dramatically improves phylogenetic fit. Mol Biol Evol 31(8):1956-1978. https://doi.org/10.1093/molbev/msu173

Bloom JD (2015) Software for the analysis and visualization of deep mutational scanning data. BMC Bioinf 16:168. https://doi. org/10.1186/s12859-015-0590-4

Bloom JD (2017) Identification of positive selection in genes is greatly improved by using experimentally informed site-specific models. Biol Direct 12:1. https://doi.org/10.1186/s13062-016-0172-z

Breiman L (2001) Random forests. Mach Learn 45(1):5-32. https:// doi.org/10.1023/A:1010933404324

Brenan L, Andreev A, Cohen O, Pantel S, Kamburov A, Cacchiarelli D, Persky NS, Zhu C, Bagul M, Goetz EM, Burgin AB, Garraway LA, Getz G, Mikkelsen TS, Piccioni F, Root DE, Johannessen CM (2016) Phenotypic characterization of a comprehensive set of MAPK1/ERK2 missense mutants. Cell Rep 17(4):1171-1183. https://doi.org/10.1016/j.celrep.2016.09.061

Cadwell RC, Joyce GF (1994) Mutagenic PCR. Genome Res 3(6):S136-S140

Chan YH, Venev SV, Zeldovich KB, Matthews CR (2017) Correlation of fitness landscapes from three orthologous TIM barrels originates from sequence and structure constraints. Nat Commun 8:14614. https://doi.org/10.1038/ncomms14614

Cheon JY, Mozersky J, Cook-Deegan R (2014) Variants of uncertain significance in BRCA: a harbinger of ethical and policy issues to come? Genome Med 6:121. https://doi.org/10.1186/s1307 3-014-0121-3

Chesmore K, Bartlett J, Williams SM (2018) The ubiquity of pleiotropy in human disease. Hum Genet 137(1):39-44. https://doi. org/10.1007/s00439-017-1854-z 
Choi Y, Sims GE, Murphy S, Miller JR, Chan AP (2012) Predicting the functional effect of amino acid substitutions and indels. PLos One 7(10):e46688. https://doi.org/10.1371/journal.pone.0046688

Deng Z, Huang W, Bakkalbasi E, Brown NG, Adamski CJ, Rice K, Muzny D, Gibbs RA, Palzkill T (2012) Deep sequencing of systematic combinatorial libraries reveals $\beta$-lactamase sequence constraints at high resolution. J Mol Biol 424(3):150-167. https ://doi.org/10.1016/j.jmb.2012.09.014

Doud MB, Bloom JD (2016) Accurate measurement of the effects of all amino-acid mutations on influenza hemagglutinin. Viruses 8(6):155. https://doi.org/10.3390/v8060155

Doud MB, Ashenberg O, Bloom JD (2015) Site-specific amino acid preferences are mostly conserved in two closely related protein homologs. Mol Biol Evol 32(11):2944-2960. https://doi. org $/ 10.1093 / \mathrm{molbev} / \mathrm{msv} 167$

Edwards SL, Beesley J, French JD, Dunning AM (2013) Beyond GWASs: illuminating the dark road from association to function. Am J Hum Genet 93(5):779-797. https://doi. org/10.1016/j.ajhg.2013.10.012

Ernst A, Gfeller D, Kan Z, Seshagiri S, Kim PM, Bader GD, Sidhu SS (2010) Coevolution of PDZ domain-ligand interactions analyzed by high-throughput phage display and deep sequencing. Mol BioSyst 6(10):1782-1790. https://doi.org/10.1039/ C0MB00061B

Fields S, Song OK (1989) A novel genetic system to detect protein-protein interactions. Nature 340:245-246. https://doi. org/10.1038/340245a0

Findlay GM, Boyle EA, Hause RJ, Klein JC, Shendure J (2014) Saturation editing of genomic regions by multiplex homology-directed repair. Nature 513(7516):120-123. https://doi.org/10.1038/natur e13695

Findlay GM, Daza RM, Martin B, Zhang MD, Leith AP, Gasperini M, Janizek JD, Huang X, Starita LM, Shendure J (2018) Accurate functional classification of thousands of BRCA1 variants with saturation genome editing. bioRxiv 294520. https://doi. org/10.1101/294520

Firnberg E, Ostermeier M (2012) PFunkel: efficient, expansive, userdefined mutagenesis. PLoS One 7(12):e52031. https://doi. org/10.1371/journal.pone.0052031

Firnberg E, Labonte JW, Gray JJ, Ostermeier M (2014) A comprehensive, high-resolution map of a gene's fitness landscape. Mol Biol Evol 31(6):1581-1592. https://doi.org/10.1093/molbev/msu081

Forsyth CM, Juan V, Akamatsu Y, DuBridge RB, Doan M, Ivanov AV, Ma Z, Polakoff D, Razo J, Wilson K, Powers DB (2013) Deep mutational scanning of an antibody against epidermal growth factor receptor using mammalian cell display and massively parallel pyrosequencing. mAbs 5(4):523-532. https://doi. org/10.4161/mabs.24979

Fowler DM, Araya CL, Fleishman SJ, Kellogg EH, Stephany JJ, Baker D, Fields S (2010) High-resolution mapping of protein sequencefunction relationships. Nat Methods 7(9):741-746. https://doi. org/10.1038/nmeth.1492

Fowler DM, Araya CL, Gerard W, Fields S (2011) Enrich: software for analysis of protein function by enrichment and depletion of variants. Bioinformatics 27(24):3430-3431. https://doi.org/10.1093/ bioinformatics/btr577

Friedman JH (2001) Greedy function approximation: a gradient boosting machine. Ann Stat 29(5):1189-1232. http://www.jstor.org/ stable/2699986

Fujino Y, Fujita R, Wada K, Fujishige K, Kanamori T, Hunt L, Shimizu Y, Ueda T (2012) Robust in vitro affinity maturation strategy based on interface-focused high-throughput mutational scanning. Biochem Biophys Res Commun 428(3):395-400. https:// doi.org/10.1016/j.bbrc.2012.10.066

Gray VE, Hause RJ, Luebeck J, Shendure J, Fowler DM (2018) Quantitative missense variant effect prediction using large-scale mutagenesis data. Cell Syst 6(1):116-124.e3. https://doi. org/10.1016/j.cels.2017.11.003

Hart T, Chandrashekhar M, Aregger M, Steinhart Z, Brown KR, MacLeod G, Mis M, Zimmermann M, Fradet-Turcotte A, Sun S, Mero P, Dirks P, Sidhu S, Roth FP, Rissland OS, Durocher D, Angers S, Moffat J (2015) High-resolution CRISPR screens reveal fitness genes and genotype-specific cancer liabilities. Cell 163(6):1515-1526. https://doi.org/10.1016/j.cell.2015.11.015

Hiatt JB, Patwardhan RP, Turner EH, Lee C, Shendure J (2010) Parallel, tag-directed assembly of locally derived short sequence reads. Nat Methods 7(2):119-122. https://doi.org/10.1038/nmeth .1416

Hietpas RT, Jensen JD, Bolon DNA (2011) Experimental illumination of a fitness landscape. PNAS 108(19):7896-7901. https://doi. org/10.1073/pnas.1016024108

Hietpas RT, Bank C, Jensen JD, Bolon DNA (2013) Shifting fitness landscapes in response to altered environments. Evolution 67(12):3512-3522. https://doi.org/10.1111/evo.12207

Hoggard T, Liachko I, Burt C, Meikle T, Jiang K, Craciun G, Dunham MJ, Fox CA (2016) High throughput analyses of budding yeast ARSs reveal new DNA elements capable of conferring centromere-independent plasmid propagation. G3 Genes Genomes Genet 6(4):993-1012. https://doi.org/10.1534/g3.116.027904

Hutchison CA, Phillips S, Edgell MH, Gillam S, Jahnke P, Smith M (1978) Mutagenesis at a specific position in a DNA sequence. J Biol Chem 253(18):6551-6560

Jacquier H, Birgy A, Nagard HL, Mechulam Y, Schmitt E, Glodt J, Bercot B, Petit E, Poulain J, Barnaud G, Gros PA, Tenaillon O (2013) Capturing the mutational landscape of the beta-lactamase TEM-1. PNAS 110(32):13067-13072. https://doi.org/10.1073/ pnas. 1215206110

Jain PC, Varadarajan R (2014) A rapid, efficient, and economical inverse polymerase chain reaction-based method for generating a site saturation mutant library. Anal Biochem 449:90-98. https ://doi.org/10.1016/j.ab.2013.12.002

Jiang L, Mishra P, Hietpas RT, Zeldovich KB, Bolon DNA (2013) Latent effects of Hsp90 mutants revealed at reduced expression levels. PLos Genet 9(6):e1003600. https://doi.org/10.1371/journ al.pgen. 1003600

Julien P, Miñana B, Baeza-Centurion P, Valcárcel J, Lehner B (2016) The complete local genotype-phenotype landscape for the alternative splicing of a human exon. Nat Commun 7:11558. https:// doi.org/10.1038/ncomms11558

Julius MH, Masuda T, Herzenberg LA (1972) Demonstration that antigen-binding cells are precursors of antibody-producing cells after purification with a fluorescence-activated cell sorter. PNAS 69(7):1934-1938

Kaplanis J, Akawi N, Gallone G, McRae JF, Prigmore E, Wright CF, Fitzpatrick DR, Firth HV, Barrett JC, Hurles ME (2018) Exome-wide assessment of the functional impact and pathogenicity of multi-nucleotide mutations. bioRxiv. https://doi. org/10.1101/258723

Ke S, Anquetil V, Zamalloa JR, Maity A, Yang A, Arias MA, Kalachikov S, Russo JJ, Ju J, Chasin LA (2018) Saturation mutagenesis reveals manifold determinants of exon definition. Genome Res 28(1):11-24. https://doi.org/10.1101/gr.219683.116

Kim I, Miller CR, Young DL, Fields S (2013) High-throughput analysis of in vivo protein stability. Mol Cell Proteom 12(11):3370-3378. https://doi.org/10.1074/mcp.O113.031708

Kitzman JO, Starita LM, Lo RS, Fields S, Shendure J (2015) Massively parallel single-amino-acid mutagenesis. Nat Meth 12(3):203206. https://doi.org/10.1038/nmeth.3223

Klesmith JR, Bacik JP, Wrenbeck EE, Michalczyk R, Whitehead TA (2017) Trade-offs between enzyme fitness and solubility illuminated by deep mutational scanning. PNAS 114(9):2265-2270. https://doi.org/10.1073/pnas.1614437114 
Kohsaka S, Nagano M, Ueno T, Suehara Y, Hayashi T, Shimada N, Takahashi K, Suzuki K, Takamochi K, Takahashi F, Mano H (2017) A method of high-throughput functional evaluation of EGFR gene variants of unknown significance in cancer. Sci Transl Med 9(416):eaan6566. https://doi.org/10.1126/scitranslm ed.aan6566

Kosuri S, Eroshenko N, LeProust EM, Super M, Way J, Li JB, Church GM (2010) Scalable gene synthesis by selective amplification of DNA pools from high-fidelity microchips. Nat Biotechnol 28(12):1295-1299. https://doi.org/10.1038/nbt.1716

Kotler E, Shani O, Goldfeld G, Lotan-Pompan M, Tarcic O, Gershoni A, Hopf TA, Marks DS, Oren M, Segal E (2018) A systematic p53 mutation library links differential functional impact to cancer mutation pattern and evolutionary conservation. Mol Cell 71(1):178-190.e8. https://doi.org/10.1016/j.molcel.2018.06.012

Kunkel TA (1985) Rapid and efficient site-specific mutagenesis without phenotypic selection. PNAS 82(2):488-492

Kwasnieski JC, Mogno I, Myers CA, Corbo JC, Cohen BA (2012) Complex effects of nucleotide variants in a mammalian cis-regulatory element. Proc Natl Acad Sci 109(47):19498-19503. https ://doi.org/10.1073/pnas.1210678109

Lee MG, Nurse P (1987) Complementation used to clone a human homologue of the fission yeast cell cycle control gene cdc2. Nature 327(6117):31-35. https://doi.org/10.1038/327031a0

Li C, Qian W, Maclean CJ, Zhang J (2016) The fitness landscape of a tRNA gene. Science 352(6287):837-840. https://doi. org/10.1126/science.aae 0568

Liachko I, Youngblood RA, Keich U, Dunham MJ (2013) High-resolution mapping, characterization, and optimization of autonomously replicating sequences in yeast. Genome Res 23(4):698704. https://doi.org/10.1101/gr.144659.112

Ma L, Boucher JI, Paulsen J, Matuszewski S, Eide CA, Ou J, Eickelberg G, Press RD, Zhu LJ, Druker BJ, Branford S, Wolfe SA, Jensen JD, Schiffer CA, Green MR, Bolon DN (2017) CRISPRCas9-mediated saturated mutagenesis screen predicts clinical drug resistance with improved accuracy. PNAS 114(44):1175111756. https://doi.org/10.1073/pnas.1708268114

Majithia AR, Tsuda B, Agostini M, Gnanapradeepan K, Rice R, Peloso G, Patel KA, Zhang X, Broekema MF, Patterson N, Duby M, Sharpe T, Kalkhoven E, Rosen ED, Barroso I, Ellard S, UK Monogenic Diabetes Consortium, Kathiresan S, Myocardial Infarction Genetics Consortium, O'Rahilly S, UK Congenital Lipodystrophy Consortium, Chatterjee K, Florez JC, Mikkelsen T, Savage DB, Altshuler D (2016) Prospective functional classification of all possible missense variants in PPARG. Nat Genet 48(12):1570-1575. https://doi.org/10.1038/ng.3700

Maricque BB, Dougherty JD, Cohen BA (2017) A genome-integrated massively parallel reporter assay reveals dna sequence determinants of cis-regulatory activity in neural cells. Nucleic Acids Res 45(4):e16. https://doi.org/10.1093/nar/gkw942

Matreyek KA, Stephany JJ, Fowler DM (2017) A platform for functional assessment of large variant libraries in mammalian cells. Nucleic Acids Res 45(11):e102-e102. https://doi.org/10.1093/ nar/gkx183

Matreyek KA, Starita LM, Stephany JJ, Martin B, Chiasson MA, Gray VE, Kircher M, Khechaduri A, Dines JN, Hause RJ, Bhatia S, Evans WE, Relling MV, Yang W, Shendure J, Fowler DM (2018) Multiplex assessment of protein variant abundance by massively parallel sequencing. bioRxiv 211011. https://doi. org/10.1101/211011

Mattheakis LC, Bhatt RR, Dower WJ (1994) An in vitro polysome display system for identifying ligands from very large peptide libraries. PNAS 91(19):9022-9026

Maurano MT, Humbert R, Rynes E, Thurman RE, Haugen E, Wang H, Reynolds AP, Sandstrom R, Qu H, Brody J, Shafer A, Neri F, Lee K, Kutyavin T, Stehling-Sun S, Johnson AK, Canfield TK, Giste
E, Diegel M, Bates D, Hansen RS, Neph S, Sabo PJ, Heimfeld S, Raubitschek A, Ziegler S, Cotsapas C, Sotoodehnia N, Glass I, Sunyaev SR, Kaul R, Stamatoyannopoulos JA (2012) Systematic localization of common disease-associated variation in regulatory DNA. Science. https://doi.org/10.1126/science.1222794

Mavor D, Barlow K, Thompson S, Barad BA, Bonny AR, Cario CL, Gaskins G, Liu Z, Deming L, Axen SD, Caceres E, Chen W, Cuesta A, Gate RE, Green EM, Hulce KR, Ji W, Kenner LR, Mensa B, Morinishi LS, Moss SM, Mravic M, Muir RK, Niekamp S, Nnadi CI, Palovcak E, Poss EM, Ross TD, Salcedo EC, See SK, Subramaniam M, Wong AW, Li J, Thorn KS, Conchúir SO, Roscoe BP, Chow ED, DeRisi JL, Kortemme T, Bolon DN, Fraser JS (2016) Determination of ubiquitin fitness landscapes under different chemical stresses in a classroom setting. eLife 5:e15802. https://doi.org/10.7554/eLife.15802

Maxwell KN, Hart SN, Vijai J, Schrader KA, Slavin TP, Thomas T, Wubbenhorst B, Ravichandran V, Moore RM, Hu C, Guidugli L, Wenz B, Domchek SM, Robson ME, Szabo C, Neuhausen SL, Weitzel JN, Offit K, Couch FJ, Nathanson KL (2016) Evaluation of ACMG-guideline-based variant classification of cancer susceptibility and non-cancer-associated genes in families affected by breast cancer. Am J Hum Genet 98(5):801-817. https://doi.org/10.1016/j.ajhg.2016.02.024

McLaughlin RN Jr, Poelwijk FJ, Raman A, Gosal WS, Ranganathan $R$ (2012) The spatial architecture of protein function and adaptation. Nature 491(7422):138-142. https://doi.org/10.1038/ nature 11500

Melamed D, Young DL, Gamble CE, Miller CR, Fields S (2013) Deep mutational scanning of an RRM domain of the Saccharomyces cerevisiae poly(A)-binding protein. RNA 19(11):1537-1551. https://doi.org/10.1261/rna.040709.113

Melnikov A, Rogov P, Wang L, Gnirke A, Mikkelsen TS (2014) Comprehensive mutational scanning of a kinase in vivo reveals substrate-dependent fitness landscapes. Nucl Acids Res 42(14):e112-e112. https://doi.org/10.1093/nar/gku511

Mighell TL, Evans-Dutson S, O'Roak BJ (2018) A saturation mutagenesis approach to understanding PTEN lipid phosphatase activity and genotype-phenotypes relationships. bioRxiv 255265. https://doi.org/10.1101/255265

Mishra P, Flynn JM, Starr TN, Bolon DNA (2016) Systematic mutant analyses elucidate general and client-specific aspects of Hsp90 function. Cell Rep 15(3):588-598. https://doi.org/10.1016/j. celrep.2016.03.046

Mohan U, Kaushik S, Banerjee UC (2011) PCR based random mutagenesis approach for a defined DNA sequence using the mutagenic potential of oxidized nucleotide products. Open Biotechnol J 5(1):21-27. https://doi.org/10.2174/1874070701 105010021

Ng PC, Henikoff S (2001) Predicting deleterious amino acid substitutions. Genome Res 11(5):863-874. https://doi.org/10.1101/ gr.176601

Olson CA, Wu NC, Sun R (2014) A comprehensive biophysical description of pairwise epistasis throughout an entire protein domain. Curr Biol 24(22):2643-2651. https://doi. org/10.1016/j.cub.2014.09.072

Osborn MJ, Miller JR (2007) Rescuing yeast mutants with human genes. Br Funct Genom 6(2):104-111. https://doi.org/10.1093/ bfgp/elm017

Pal G, Fellouse FA (2005) Methods for the construction of phagedisplayed libraries. In: Phage display in biotechnology and drug discovery, drug discovery series, CRC Press, pp 111-142. https://doi.org/10.1201/9780849359125.ch3

Plesa C, Sidore AM, Lubock NB, Zhang D, Kosuri S (2018) Multiplexed gene synthesis in emulsions for exploring protein functional landscapes. Science 359(6373):343-347. https:// doi.org/10.1126/science.aao5167 
Procko E, Hedman R, Hamilton K, Seetharaman J, Fleishman SJ, Su M, Aramini J, Kornhaber G, Hunt JF, Tong L, Montelione GT, Baker D (2013) Computational design of a protein-based enzyme inhibitor. J Mol Biol 425(18):3563-3575. https://doi. org/10.1016/j.jmb.2013.06.035

Puchta O, Cseke B, Czaja H, Tollervey D, Sanguinetti G, Kudla G (2016) Network of epistatic interactions within a yeast snoRNA. Science 352(6287):840-844. https://doi.org/10.1126/ science.aaf0965

Qi H, Olson CA, Wu NC, Ke R, Loverdo C, Chu V, Truong S, Remenyi R, Chen Z, Du Y, Su SY, Al-Mawsawi LQ, Wu TT, Chen SH, Lin CY, Zhong W, Lloyd-Smith JO, Sun R (2014) A quantitative high-resolution genetic profile rapidly identifies sequence determinants of hepatitis $\mathrm{C}$ viral fitness and drug sensitivity. PLOS Pathogens 10(4):e1004064. https://doi. org/10.1371/journal.ppat.1004064

Reich L, Dutta S, Keating AE (2015) Sortcery-a high-throughput method to affinity rank peptide ligands. J Mol Biol 427(11):2135-2150. https://doi.org/10.1016/j.jmb.2014.09.025 (oMICS Approaches to Unravel Molecular Function)

Richards S, Aziz N, Bale S, Bick D, Das S, Gastier-Foster J, Grody WW, Hegde M, Lyon E, Spector E, Voelkerding K, Rehm HL, Committee obotALQA (2015) Standards and guidelines for the interpretation of sequence variants: a joint consensus recommendation of the American College of Medical Genetics and Genomics and the Association for Molecular Pathology. Genet Med 17(5):405-423. https://doi.org/10.1038/gim.2015.30

Rockah-Shmuel L, Tóth-Petróczy A, Tawfik DS (2015) Systematic mapping of protein mutational space by prolonged drift reveals the deleterious effects of seemingly neutral mutations. PLos Comput Biol 11(8):e1004421. https://doi.org/10.1371/journ al.pcbi. 1004421

Roscoe BP, Bolon DNA (2014) Systematic exploration of ubiquitin sequence, E1 activation efficiency, and experimental fitness in yeast. J Mol Biol 426(15):2854-2870. https://doi.org/10.1016/j. jmb.2014.05.019

Roscoe BP, Thayer KM, Zeldovich KB, Fushman D, Bolon DN (2013) Analyses of the effects of all ubiquitin point mutants on yeast growth rate. J Mol Biol 425(8):1363-1377. https://doi. org/10.1016/j.jmb.2013.01.032

Rubin AF, Lucas N, Bajjalieh SM, Papenfuss AT, Speed TP, Fowler DM (2016) Enrich2: a statistical framework for analyzing deep mutational scanning data. bioRxiv 075150, https://doi. org/10.1101/075150

Sahni N, Yi S, Taipale M, Fuxman Bass JI, Coulombe-Huntington J, Yang F, Peng J, Weile J, Karras GI, Wang Y, Kovács IA, Kamburov A, Krykbaeva I, Lam MH, Tucker G, Khurana V, Sharma A, Liu YY, Yachie N, Zhong Q, Shen Y, Palagi A, San-Miguel A, Fan C, Balcha D, Dricot A, Jordan DM, Walsh JM, Shah AA, Yang X, Stoyanova AK, Leighton A, Calderwood MA, Jacob Y, Cusick ME, Salehi-Ashtiani K, Whitesell LJ, Sunyaev S, Berger B, Barabási AL, Charloteaux B, Hill DE, Hao T, Roth FP, Xia Y, Walhout AJM, Lindquist S, Vidal M (2015) Widespread macromolecular interaction perturbations in human genetic disorders. Cell 161(3):647-660. https://doi.org/10.1016/j.cell.2015.04.013

Sarkisyan KS, Bolotin DA, Meer MV, Usmanova DR, Mishin AS, Sharonov GV, Ivankov DN, Bozhanova NG, Baranov MS, Soylemez O, Bogatyreva NS, Vlasov PK, Egorov ES, Logacheva MD, Kondrashov AS, Chudakov DM, Putintseva EV, Mamedov IZ, Tawfik DS, Lukyanov KA, Kondrashov FA (2016) Local fitness landscape of the green fluorescent protein. Nature 533(7603):397401. https://doi.org/10.1038/nature17995

Schlinkmann KM, Honegger A, Tureci E, Robison KE, Lipovsek D, Pluckthun A (2012) Critical features for biosynthesis, stability, and functionality of a $\mathrm{G}$ protein-coupled receptor uncovered by all-versus-all mutations. Proc Natl Acad Sci 109(25):9810-9815. https://doi.org/10.1073/pnas.1202107109

Scott JK, Smith GP (1990) Searching for peptide ligands with an epitope library. Science 249(4967):386-390. https://doi. org/10.1126/science. 1696028

Seyfang A, Jin JH (2004) Multiple site-directed mutagenesis of more than 10 sites simultaneously and in a single round. Anal Biochem 324(2):285-291. https://doi.org/10.1016/j.ab.2003.10.012

Shah NP, Nicoll JM, Nagar B, Gorre ME, Paquette RL, Kuriyan J, Sawyers CL (2002) Multiple BCR-ABL kinase domain mutations confer polyclonal resistance to the tyrosine kinase inhibitor imatinib (STI571) in chronic phase and blast crisis chronic myeloid leukemia. Cancer Cell 2(2):117-125. https://doi. org/10.1016/S1535-6108(02)00096-X

Smith GP (1985) Filamentous fusion phage: novel expression vectors that display cloned antigens on the virion surface. Science 228(4705):1315-1317

Solit DB, Garraway LA, Pratilas CA, Sawai A, Getz G, Basso A, Ye Q, Lobo JM, She Y, Osman I, Golub TR, Sebolt-Leopold J, Sellers WR, Rosen N (2006) BRAF mutation predicts sensitivity to MEK inhibition. Nature 439(7074):358-362. https://doi. org/10.1038/nature04304

Starita LM, Pruneda JN, Lo RS, Fowler DM, Kim HJ, Hiatt JB, Shendure J, Brzovic PS, Fields S, Klevit RE (2013) Activityenhancing mutations in an E3 ubiquitin ligase identified by highthroughput mutagenesis. Proc Natl Acad Sci 110(14):E1263E1272. https://doi.org/10.1073/pnas.1303309110

Starita LM, Young DL, Islam M, Kitzman JO, Gullingsrud J, Hause RJ, Fowler DM, Parvin JD, Shendure J, Fields S (2015) Massively parallel functional analysis of BRCA1 RING domain variants. Genetics genetics.115. https://doi.org/10.1534/genet ics.115.175802

Starita LM, Ahituv N, Dunham MJ, Kitzman JO, Roth FP, Seelig G, Shendure J, Fowler DM (2017) Variant interpretation: functional assays to the rescue. Am J Hum Genet 101(3):315-325. https:// doi.org/10.1016/j.ajhg.2017.07.014

Starita LM, Islam MM, Banerjee T, Adamovich AI, Gullingsrud J, Fields S, Shendure J, Parvin JD (2018) A multiplexed homology-directed DNA repair assay reveals the impact of 1,700 BRCA1 variants on protein function. bioRxiv 295279. https:// doi.org/10.1101/295279

Steinberg B, Ostermeier M (2016) Shifting fitness and epistatic landscapes reflect trade-offs along an evolutionary pathway. J Mol Biol 428(13):2730-2743. https://doi.org/10.1016/j. jmb.2016.04.033

Stiffler MA, Hekstra DR, Ranganathan R (2015) Evolvability as a function of purifying selection in TEM- $1 \beta$-lactamase. Cell 160(5):882-892. https://doi.org/10.1016/j.cell.2015.01.035

Sun S, Yang F, Tan G, Costanzo M, Oughtred R, Hirschman J, Theesfeld CL, Bansal P, Sahni N, Yi S, Yu A, Tyagi T, Tie C, Hill DE, Vidal M, Andrews BJ, Boone C, Dolinski K, Roth FP (2016) An extended set of yeast-based functional assays accurately identifies human disease mutations. Genome Res 26(5):670-680. https ://doi.org/10.1101/gr.192526.115

Taşan M, Musso G, Hao T, Vidal M, MacRae CA, Roth FP (2015) Selecting causal genes from genome-wide association studies via functionally coherent subnetworks. Nat Methods 12(2):154-159. https://doi.org/10.1038/nmeth.3215

The 1000 Genomes Project Consortium (2015) A global reference for human genetic variation. Nature 526(7571):68-74. https://doi. org/10.1038/nature 15393

Thyagarajan B, Bloom JD (2014) The inherent mutational tolerance and antigenic evolvability of influenza hemagglutinin. eLife 3:e03300. https://doi.org/10.7554/eLife.03300 
Tinberg CE, Khare SD, Dou J, Doyle L, Nelson JW, Schena A, Jankowski W, Kalodimos CG, Johnsson K, Stoddard BL, Baker D (2013) Computational design of ligand-binding proteins with high affinity and selectivity. Nature 501(7466):212-216. https:// doi.org/10.1038/nature12443

Traxlmayr MW, Hasenhindl C, Hackl M, Stadlmayr G, Rybka JD, Borth N, Grillari J, Rüker F, Obinger C (2012) Construction of a stability landscape of the $\mathrm{CH} 3$ domain of human IgG1 by combining directed evolution with high throughput sequencing. J Mol Biol 423(3):397-412. https://doi.org/10.1016/j.jmb.2012.07.017

Tripathi A, Gupta K, Khare S, Jain PC, Patel S, Kumar P, Pulianmackal AJ, Aghera N, Varadarajan R (2016) Molecular determinants of mutant phenotypes, inferred from saturation mutagenesis data. Mol Biol Evol 33(11):2960-2975. https://doi.org/10.1093/molbe $\mathrm{v} / \mathrm{msw} 182$

Wagenaar TR, Ma L, Roscoe B, Park SM, Bolon DN, Green MR (2014) Resistance to vemurafenib resulting from a novel mutation in the BRAFV600e kinase domain. Pigment Cell Melanoma Res 27(1):124-133. https://doi.org/10.1111/pcmr.12171

Wang T, Wei JJ, Sabatini DM, Lander ES (2014) Genetic screens in human cells using the CRISPR-Cas9 system. Science 343(6166):80-84. https://doi.org/10.1126/science.1246981

Weile J, Sun S, Cote AG, Knapp J, Verby M, Mellor JC, Wu Y, Pons C, Wong C, Lieshout Nv, Yang F, Tasan M, Tan G, Yang S, Fowler DM, Nussbaum R, Bloom JD, Vidal M, Hill DE, Aloy P, Roth FP (2017) A framework for exhaustively mapping functional missense variants. Mol Syst Biol 13(12):957. https://doi. org/10.15252/msb.20177908
Whitehead TA, Chevalier A, Song Y, Dreyfus C, Fleishman SJ, De Mattos C, Myers CA, Kamisetty H, Blair P, Wilson IA, Baker D (2012) Optimization of affinity, specificity and function of designed influenza inhibitors using deep sequencing. Nat Biotechnol 30(6):543-548. https://doi.org/10.1038/nbt.2214

Wu NC, Young AP, Dandekar S, Wijersuriya H, Al-Mawsawi LQ, Wu TT, Sun R (2013) Systematic identification of H274y compensatory mutations in influenza a virus neuraminidase by highthroughput screening. J Virol 87(2):1193-1199. https://doi. org/10.1128/JVI.01658-12

Wu NC, Olson CA, Du Y, Le S, Tran K, Remenyi R, Gong D, AlMawsawi LQ, Qi H, Wu TT, Sun R (2015) Functional constraint profiling of a viral protein reveals discordance of evolutionary conservation and functionality. PLoS Genet 11(7):e1005310. https://doi.org/10.1371/journal.pgen.1005310

Wu NC, Anders OC, Sun R (2016) High-throughput identification of protein mutant stability computed from a double mutant fitness landscape. Protein Sci 25(2):530-539. https://doi.org/10.1002/ pro. 2840

Yang M, Wu Z, Fields S (1995) Protein-peptide interactions analyzed with the yeast two-hybrid system. Nucl Acids Res 23(7):11521156. https://doi.org/10.1093/nar/23.7.1152

Zhang TH, Wu NC, Sun R (2016) A benchmark study on error-correction by read-pairing and tag-clustering in amplicon-based deep sequencing. BMC Genom 17:108. https://doi.org/10.1186/s1286 4-016-2388-9 